\title{
Anti-Inflammatory Activities of Ethyl Acetate Fraction From Uncaria Gambir Leaves Through the Inhibition of Edema, COX-2 and iNOS Expression
}

\author{
Nanang Yunarto ${ }^{1}$, Putri Reno Intan ${ }^{1}$, Arifayu Addiena Kurniatri ${ }^{1}$, \\ Indah Sulistyowati ${ }^{1}$, Nurul Aini ${ }^{1}$ \\ ${ }^{I}$ Center for Research and Development on Biomedical and Basic Health Technology, Indonesia \\ *Corresponding author.Email: nayunandesba@yahoo.com
}

\begin{abstract}
Inflammatory is a body defense mechanism due to respond of tissue on undermine influences, either local or the one that go into the body. Inflammatory can cause various physical dysfunctions. Uncaria gambir Roxb, a high catechin content in ethyl acetate fraction, is widely used as wound healing in Indonesian culture, therefore its mechanism of anti-inflammatory action is still unknown. The objective of our study is to investigated the activity of anti-inflammatory ethyl acetate fraction of Uncaria gambir leaves inhibition of edema, COX-2 and iNOS expression using induction method with carrageenan in rats. This study is experimental research which use 25 white Wistar strain rats as animals assay that divided into 5 groups: negative group (water), positive group (sodium diclofenac $50 \mathrm{mg} / \mathrm{kg} \mathrm{bw}$ ), dose I ( $5 \mathrm{mg} / \mathrm{kg}$ bw fraction), II (10 $\mathrm{mg} / \mathrm{kg}$ bw fraction) and III ( $20 \mathrm{mg} / \mathrm{kg}$ bw fraction) groups. Each of them were given orally $30 \mathrm{~min}$ before carrageenan 3\% induced. The paw volume was measured every day for seven day after injection carrageenan using plethysmometer. Inhibition COX-2 and iNOS expression were determined by enzyme-linked immunosorbent assay. The results showed that ethyl acetate fraction of Uncaria gambir leaves in all doses had anti-inflammatory effect on white rats through the mechanism of inflammatory inhibition by reducing edema volume. All three fraction doses can also reduce COX-2 and iNOS expression. The fraction had the highest anti-inflammatory potency by the dose of $20 \mathrm{mg} / \mathrm{kg}$ body weight. The conclusion that ethyl acetate of three doses had anti-inflammatory activities through a mechanism of edema volume reduction, COX-2 and iNOS expression.
\end{abstract}

Keywords: anti-inflammatory, edema, COX-2, iNOS

\section{INTRODUCTION}

Inflammation is considered as complex case that happened due to injured body, caused by chemical material or selfdestructive (autoimunne). Inflamation is a protective respond as bodies' effort to return the condition as before injury (preinjury) or self-healing after injury. Inflammation respond is protective reaction and an important body restorative because the human body is trying to maintain the homeostatic under harmful envireonment. Inflamation cause many substances out endogenously, known as inflammation mediator. Arachidonic acid is one of the important inflammation mediator. Arachidonic acid important in prostaglandin biosynthesis through cyclooxygenase [1][2].

Control of pain and edema can increase immune respond in wound healing so the cure run better. One way to control pain and edema is by inhibiting cyclooxygenase enzyme. Anti-inflammation non stereoid (ANS) as antiinflammation works through inhibiting cyclooxygenase and inhibiting the migration of inflammation cells and cels adhesion expression. Antiinflammation non stereoid had serious adverse effect if used as peptic ulcer, decreasing of infection immunity, osteoporosis, muscle athropy and lipid, increasing intraocular pressure, and diabetics [3][4].

Cyclooxygenase-2 (COX-2) is enzyme that influenced by tissue stimulus. The stimulus can be in the form of cytokine, lipopolysaccharides bacteria, inflammation or other pathologic symptoms. Inflammation can cause leukocytes accumulation, especially neutrophils and monocytes in the injured side to eliminate or confine the wound cause agent. Controlling paint and edema can increase immune respond in wound healing so the cure run better. One way to control pain and edema is by inhibiting cyclooxygenase enzyme. Anti-inflammation non stereoid (ANS) as antiinflammation works through inhibiting cyclooxygenase and inhibiting the migration of 
inflammation cells and cels adhesion expression. Antiinflammation non stereoid can cause gastrointestinal bleeding, make bleeding longer, and ruin the kidney function [5][6][7].

Catechin is flavanoid that had proven can inhibit inflammation. One of plantation that considered have antiinflammation effect is gambier (Uncaria gambir Roxb). The plantation used empirically as the medication for burns, wound, sprue, gingivitis, sore throat, diarrhea, dysentery, cough, and fever. The main substance of gambier is catechin $(51 \%)$, tanner $(20-25 \%)$, catechutanic acid, quersetin, red catechu, fluoresein gambier, ash, fatty acid, wax, alcaloids, and tanin. Gambier chemical substances that widely use is catechin and tannin.10 The biggest chemical substances in gambier is catechin that part of flavonoid. Flavonoids fuctions as antibacterial through complex substances formation of extracellular protein that disturb the integrity of bacteria cell membrane. 11 Tanin works in gambier as antibacterial and antifungi. Tanin can be used as adstringen that contraction skin pores, harden skin, stop small bleeding, antiseptic, and burns.8 Ethyl acetate fraction of gambier leaves inhibitory activity on COX2 and iNOS enzymes unclarified. The objective of our study is to investigated the activity of anti-inflammatory ethyl acetate fraction of Uncaria gambir leaves inhibition of edema, COX-2 and iNOS expression using induction method with carrageenan in rats

\section{METHOD}

\section{Materials}

Gambier leaves extract from Lima puluh Kota district, catechin standard (Sigma Aldrich, Germany), ethyl acetate, aquadest, methanol HPLC grade (Merck), trifluoroacetic acid (Merck), acetonitrile HPLC grade (Merck), galur wistar mice, COX2 inhibitor screening assay kit, iNOS inhibitor screening assay kit.

\section{Equipment}

Fractionation coloumn, rotary evaporator (Buchi R114), oven (Memmert), High pressure liquid chromatography (HPLC) (Waters Alliance 2695), ELISA.

\section{Extraction}

Making gambir leaf extract begins with harvesting fresh leaves on a large tree and leaves taken about 5 strands from the shoots. Furthermore, fresh gambier leaves are put into a net and steamed with hot water vapor for 90 minutes. Gambier leaves that have been finished steamed, are removed and compressed using a hydraulic press to obtain gambier sap. Gambir sap drained and collected in a baking sheet, then cooled for $2 \times 24$ hours at room temperature until hard. Hardened gambier sap is printed with cylindrical molds. To minimize the moisture content, the drying process is continued using an oven at $40-50{ }^{\circ} \mathrm{C}$ for 1 x 24 hours. 9

\section{Fractionation}

The fractionation process was carried out by using $200 \mathrm{~g}$ of gambir leaf extract that crushed until smooth, suspended in n-hexane solvent and homogenized using a sonicator for 10 minutes. The suspension is filtered using filter paper. The residue was dissolved in ethyl acetate solvent, then homogenized with a sonicator for 10 minutes. The solution is partitioned by adding distilled water, then shaken in a separating flask and allowed to stand for 30-60 minutes until there are two layers (ethyl acetate layer at the top and distilled layer at the bottom). The two layers formed are then separated. The ethyl acetate fraction layer was evaporated using a rotary evaporator until thick. The ethyl acetate fraction obtained was evaporated in a fume hood, then continued drying in a vacuum oven at $40-50{ }^{\circ} \mathrm{C}$ until a fixed weight was obtained [9].

\section{Determination of Catechin Levels}

Samples of ethyl acetate fraction were analyzed using HPLC Waters, Sun Fire C18 column $4.6 \times 150 \mathrm{~mm}$, with a flow rate of $0.45 \mathrm{~mL} / \mathrm{min}$, injection volume of $1.0 \mu \mathrm{L}$ and a detector using UV at a wavelength of $280 \mathrm{~nm}$. The mobile phase is used gradiently with the mobile phase A: $0.1 \%$ trifluoroacetic acid in a mixture of acetonitrile: water (5:95) and the mobile phase B $0.1 \%$ triflouroacetic acid in acetonitrile. The gradient conditions of the mobile phase are 0-4 minutes $(100 \%$ A) 4-20 minutes $(71.5 \mathrm{~A} ; 28.5 \mathrm{~B})$ and $20-30$ minutes $(100 \% \mathrm{~B})[10]$.

\section{Anti-inflammatory Test of Edema Volume Method}

Tested animals were completely randomized that divided into 5 treatment groups consisting of negative controls, positive controls, doses I, II and III, namely the groups that were given test samples at doses of 5, 10, $20 \mathrm{mg} / \mathrm{kg} \mathrm{BW}$. The treatments for each test group are in table 1.

Table 1. Groups of tested animals

\begin{tabular}{|l|c|l|}
\hline $\begin{array}{c}\text { Evaluation } \\
\text { Group }\end{array}$ & $\begin{array}{c}\text { Number } \\
\text { of rats }\end{array}$ & \multicolumn{1}{c|}{ Treatment } \\
\hline $\begin{array}{l}\text { Negative } \\
\text { control }\end{array}$ & 5 & $\begin{array}{l}\text { Give distilled water orally and 30 minutes } \\
\text { later, injected with 3\% carrageenan as much } \\
\text { as 0.1 mL. }\end{array}$ \\
\hline $\begin{array}{l}\text { Positive } \\
\text { control }\end{array}$ & 5 & $\begin{array}{l}\text { Diclofenac sodium was given a dose of 50 } \\
\text { mg / kg bw orally and 30 minutes later it } \\
\text { was injected with 3\% carrageenan as much } \\
\text { as 0.1 mL. }\end{array}$ \\
\hline Dose I & 5 & $\begin{array}{l}\text { The experimental animal group was given } \\
\text { gambir extract at a dose of } 5 \text { mg / kg bw } \\
\text { orally and 30 minutes later it was injected } \\
\text { with 3\% carrageenan as much as 0.1 mL. }\end{array}$ \\
\hline Dose II & 5 & $\begin{array}{l}\text { The experimental animal group was given } \\
\text { gambier extract at a dose of } 10 \text { mg / kg bw } \\
\text { orally and 30 minutes later it was injected } \\
\text { with 3\% carrageenan as much as } 0.1 \mathrm{~mL} .\end{array}$ \\
\hline Dose III & 5 & $\begin{array}{l}\text { Group of experimental animals which were } \\
\text { given gambir extract at a dose of } 20 \mathrm{mg} / \mathrm{kg} \\
\text { bw orally and 30 minutes later at 3\% } \\
\text { carrageenan injection of 0.1 mL }\end{array}$ \\
\hline
\end{tabular}


used consisted of iNOS Assay Buffer solution, iNOS Probe (in DMSO), arachidonic acid substrate, iNOS Cofactor (in DMSO), $\mathrm{NaOH}$, and iNOS. The inhibitory ability of iNOS is shown by the lower absorbance value of the sample solution compared to the blank solution on measurements using an ELISA microplate reader at a wavelength of $570 \mathrm{~nm}$. Inhibition of enzyme activity is calculated as (\%) inhibition [13]:

$$
\% \text { inhibition }=\frac{\text { control abs }-(\text { sample abs }- \text { blank abs })}{\text { control abs }} \times 100 \%
$$

Data Analysis

Data from the experiments were expressed as mean \pm SD. The statistical significance of differences between the groups were analyzed with one-way ANOVA, followed by LSD post-hoc test analysis using SPSS software 17.0 version, $\mathrm{p}$ values of less than 0.05 were considered to indicate significant difference

\section{RESULTS AND DISCUSSION}

\section{Results}

The protocol of animal study has received the ethical clearance from Health Research Ethics Commitee National Institute Health Research and Development, Ministry of Health number LB.02.01/2/KE.103/2017. Total catechin content in the fraction derived from HPLC analysis was $95,56 \%$. The catechin content which is more than $90 \%$ met the requirement of IHP. These result was consistent with Yunarto et al that fractionation process can improve the purity and levels of catechin [14]. (COX2) enzyme

The testing of cyclooxygenase inhibition activity was carried out in vitro by the method of inhibiting the activity of COX2 enzymes on the formation of arachidonic acid by using COX2 inhibitor screening assay. The kit used consists of COX Assay Buffer solution, COX Probe (in DMSO), arachidonic acid substrate, $\mathrm{COX}$ Cofactor (in DMSO), $\mathrm{NaOH}$, and COX2. The ability to inhibit COX2 is shown by the lower absorbance value of the sample solution compared to the blank solution on measurements using an ELISA microplate reader at a wavelength of $570 \mathrm{~nm}$. Inhibition of enzyme activity is calculated as (\%) inhibition [13]:

$$
\% \text { inhibition }=\frac{\text { control abs }-(\text { sample abs }- \text { blank abs })}{\text { control abs }} \times 100 \%
$$

Induction nitric oxide synthase (iNOS) inhibitory activity test

The testing of cyclooxygenase inhibition activity was carried out in vitro by the method of inhibiting the activity of the iNOS enzyme against arachidonic acid formation using iNOS inhibitor screening assay. The kit
Table 2. Inhibition of edema (\%)

\begin{tabular}{lcccccc}
\hline \multirow{2}{*}{ Groups } & \multicolumn{7}{c}{ Average of \% edema inhibition at the -hours } \\
\cline { 2 - 7 } & 1 & 2 & 3 & 4 & 5 & 6 \\
Negative & & & & & & \\
control & 0.00 & 0.00 & 0.00 & 0.00 & 0.00 & 0.00 \\
& $18.04 \pm$ & & $34.23 \pm$ & $21.72 \pm$ & $12.64 \pm$ & \\
Positive control & 0.16 & $26.12 \pm 0.36$ & 0.22 & 0.48 & 0.31 & $8.22 \pm 0.08$ \\
& $17.92 \pm$ & & $35.14 \pm$ & $22.38 \pm$ & $13.64 \pm$ & \\
Dose I & 0.12 & $26.45 \pm 0.28$ & 0.31 & 0.25 & 0.29 & $9.04 \pm 0.07$ \\
& $24.56 \pm$ & & $39.78 \pm$ & $41.54 \pm$ & $30.64 \pm$ & $18.22 \pm$ \\
Dose II & 0.36 & $31.18 \pm 0.26$ & 0.24 & 0.28 & 0.35 & 0.16 \\
& $28.12 \pm$ & & $44.85 \pm$ & $50.22 \pm$ & $38.24 \pm$ & $28.22 \pm$ \\
Dose III & 0.32 & $35.75 \pm 0.42$ & 0.26 & 0.72 & 0.42 & 0.18 \\
\hline
\end{tabular}

Based on Table 1, at dose III (20 mg / $\mathrm{kg}$ body weight) shows the largest percentage of edema inhibition that is $28.12 \%$ in the first hour and continues to increase until the fourth hour which can inhibit edema by $50.22 \%$. Dose III had a significant difference $(p<0.05)$ with negative control, positive control, dose I and dose II in the first hour. This difference shows that dose III has a faster onset when compared to other groups. This is because the catechin content at dose III is higher when compared to doses I and II. 
in cytokine production, catechin cytokine-reducing effect may inhibit the increase in inos expression and NO levels [18].

Stable nitrite is used as a measure of NO produced from iNOS from synovial macrophages in OA. Nitric oxide may be involved in the destruction of proteoglycan in cartilage by inducing the production of matrix metalloproteinase. To assess catechin effect on the production of this highly reactive oxidative molecule, LPS-stimulated rat peritoneal macrophages expressing higher levels of iNOS were used in the presence of increasing levels of the flavonoid preparation [19].

inhibition of COX2 and iNOS activity shown that compared to positive control, doses II and III of fraction gambir leaves extract were able to inhibit of COX2 and iNOS activity. $(\mathrm{p}<0.05)$.

\section{Discussion}

The mechanism of action of ethyl acetate fraction of gambir leaves inhibiting COX-2 expression causes arachidonic acid did not turn into cyclic prostaglandin endoperoxide. Cyclic endoperoxide prostaglandin is a precursor for all prostaglandins so that prostaglandin biosynthesis is stopped. Prostaglandins function to increase the permeability of blood vessels causing neutrophil edema and chemotaxis. Thus the inhibition of cyclooxygenase enzyme activity by ethanol extract of Moringa leaves will reduce edema volume and COX-2 expression through neutrophils [15].

Poor oxidative status, as well as the production of oxidized lipids from arachidonic acid, has also been linked to chondrocyte apoptosis, activation of latent matrix metalloproteinases, and cartilage matrix degradation due to upregulation of inflammatory gene expression. Catechins are flavonoid of polyphenol groups that function as a free radical scavenger to provide the hydrogen atom. The structure that allows the radical scavenging activity of polyphenols is the presence of 3,4-dihydroxyl (catechol structure) in the $\mathrm{B}$ ring, which acts as an electron donor and became the target of radical. The $3-\mathrm{OH}$ structure of ring $\mathrm{C}$ is also beneficial to the activity of antioxidant polyphenols. Conjugation bond at $\mathrm{C} 2-\mathrm{C} 3$ with 4-keto group plays a role for the electron delocalization of the B ring, which in turn increases free radical scavenging capacity. Besides that, the $3-\mathrm{OH}$ group and $5-\mathrm{OH}$, in combination with 4-carbonyl function and $\mathrm{C} 2-\mathrm{C} 3$ double bond, also raise antioxidant activity. In the absence of odihydroxy structure in the B ring, the hydroxyl substituents on the catechol ring A can be compensated and the ability antiradikal activity of polyphenols is increased [16][17]. In our study, ethyl acetate fraction of gambir rich catechin reduced both $\mathrm{PLA}_{2}$ activity and nitrite levels in macrophages. This suggests that catechin may act to limit the conversion of phospholipids from damaged cell membranes to AA upstream of the COX and 5-LOX metabolic pathways. In addition, the reduction in nitrite, the stable breakdown product of NO, may prevent the production of matrix metalloproteinase from macrophages present in the synovium. In support of these findings, flavocoxid was previously shown to reduce iNOS protein production by an antioxidant mechanism. Since it is also known that NO levels are positively affected by increases

\section{CONCLUSION}

The ethyl acetate fraction of Uncaria gambir leaves in all doses had anti- inflammatory effect on white rats through the mechanism of inflammatory inhibition by reducing edema volume. All three fraction doses can also reduce COX-2 and iNOS expression. The fraction had the highest anti-inflammatory potency by the dose of $20 \mathrm{mg} / \mathrm{kg}$ body weight.

\section{REFERENCES}

[1] Gleeson M, Bishop NC, Stensel DJ, Lindley MR, Mastana SS, Nimmo MA. The anti-inflammatory effects of exercise: mechanisms and implications for the prevention and treatment of disease. Nature reviews immunology. 2011;11(9):607-15.

[2] Astudillo AM, Balgoma D, Balboa MA, Balsinde J. Dynamics of arachidonic acid mobilization by inflammatory cells. Biochimica et Biophysica Acta (BBA)-Molecular and Cell Biology of Lipids. 2012;1821(2):249-56.

[3] Al-Turki DA, Abou-Zeid LA, Shehata LA, AlOmar M A. Therapeutic and toxic effects of new NSAIDs and related compounds a review and prospective study. International Journal of Pharmacology. 2010;6(6): 813-25.

[4] Scheiman JM. NSAID-induced Gastrointestinal Injury. Journal of clinical gastroenterology. 2016;50(1):5-10.

[5] Wang YF, Shao SH, Xu P, Yang XQ, Qian LS. Catechin-enriched green tea extract as a safe and effective agent for antimicrobial and anti-inflammatory treatment. African Journal of Pharmacy and Pharmacology. 2011;5(12):1452-61.

[6] Serafini M, Peluso I, Raguzzini A. Flavonoids as anti-inflammatory agents. Proceedings of the Nutrition Society. 2010;69(3):273-78.

[7] Huang PL, Chi CW, Liu TY. Effects of Areca catechu L. containing procyanidins on cyclooxygenase-2 
antiinflamasi. Univesity Research Coloquium.

expression in vitro and in vivo. Food and Chemical Toxicology. 2010;48(1):306-13.

[8] Tang, L Q, Wei W, Wang XY. Effects and mechanisms of catechin for adjuvant arthritis in rats. Advances in therapy. 2007;24(3):679-90.

[9] Yunarto N, Elya B, Konadi L. Potensi fraksi etil asetat ekstrak daun gambir (Uncaria gambir Roxb.) sebagai antihiperlipidemia. Jurnal Kefarmasian Indonesia. 2015:5(1):1-10.

[10] Yunarto, N, Sulistyowati I, Kurniatri AA, Aini N. Pengaruh Penyalutan terhadap Karakteristik Fisika Kimia dan Stabilitas Tablet Fraksi Etil Asetat Daun Gambir sebagai Agen Antidislipidemia. Media Penelitian dan Pengembangan Kesehatan. 2017;27(2); $71-8$.

[11] Sujono TA, Patimah R, Yuliani R. Efek antiinflamasi infusa rimpang temu putih (Curcuma zeodoria) pada tikus yang diinduksi karagenan. J Biomedika. 2012;4(2):10-17.

[12] Rinayanti A, Dewanti E. Uji Efek Antiinflamasi Fraksi Air Daun Mahkota Dewa (Phaleria macrocarpa (Shecff.) Boerl.) terhadap Tikus Putih (Rattus norvegicus L.). Pharmaceutical Sciences and Research. 2016;1(2):78-85.

[13] Soekaryo E, Simanjuntak P, Setyahadi S. Uji inhibisi enzim siklooksigenase-2 (COX-2) dari ekstrak daun sirsak (Annona muricata linn.) sebagai
2016:485-92.

[14] Yunarto, N., \& Aini, N. Effect of purified gambir leaves extract to prevent atherosclerosis in rats. Health Science Journal of Indonesia.2015;6(2):105-10.

[15] Vardeny O, Solomon SD. Cyclooxygenase-2 inhibitors, nonsteroidal anti-inflammatory drugs, and cardiovascular risk. Cardiology clinics. 2006:26(4):589601.

[16] Kim HP, Park H, Son KH, Chang HW, Kang SS. Biochemical pharmacology of biflavonoids: implications for anti-inflammatory action. Archives of Pharmacal Research. 2008;31(3):265-73.

[17] Amic DD, Beslo D, Trinajstic. Structure-radical scavenging activity relationship of flavonoids. Journal of Croatia Chemica Acta. 2003;76(1):55-61

[18] Polito F, Bitto A, Irrera A, Flavocoxid, a dual inhibitor of cyclooxygenase-2 and 5-lipoxygenase, reduces pancreatic damage in an experimental model of acute pancreatitis. British Journal of Pharmacology. 2010;161(5):1002-11.

[19] Burnett BP, Bitto A, Altavilla D, Squadrito F, Levy RM, and Pillai L, "Flavocoxid Inhibits Phospholipase A2, Peroxidase Moieties of the Cyclooxygenases (COX), and 5-Lipoxygenase, Modifies COX-2 Gene Expression, and Acts as an Antioxidant," Mediators of Inflammation, vol. 2011, Article ID 385780, 11 pages. 